Turn to the left/right! /Left (right), face! (Поверніться наліво/направо!)

About, face! (Кругом!)

Look up/ down! (Дивіться вгору/вниз!)

Close your eyes! (Закрийте очі!)

Open your eyes! (Відрийте очі!)

Mark time, march! (На місці кроком руш!)

Forward, march! (Кроком руш!)

Double time, march! (Бігом руш!)

Фізичну культуру можна ефективно й гармонійно поєднувати з уроками англійської мови. Предметна інтеграція служить засобом збагачення змісту уроку. Інтегроване навчання забезпечує формування в учнів позитивного ставлення до іноземної мови, ознайомлення їх 3 новими поняттями, перетворення мови на реальний інструмент спілкування, практичне оволодіння лексичними компетенціями на базі реальних комунікативних ситуацій, що $\epsilon$ запорукою успіху як вивчення англійської мови в цілому, так і підвищення інтересу до виконання фізичних вправ зокрема.

\title{
Література
}

1. Jiménez G. Educación Física en inglés. Una propuesta para trabajar la higiene postural en Educación Primaria (Physical Education in English. A proposal for working postural hygiene in Primary Education) [Електронний ресурс] /García Jiménez, García Pellicer, Yuste Lucas. Режим доступу: http://recyt.fecyt.es/index.php/retos/ article/view/34589 2. Pearson P. Recommendations for policy and practice of physical education in culturally and linguistically diverse Australian secondary schools based on a two-year prospective cohort study [Електронний pecypc]/Phil Pearson, Anthony D. Okely, Wayne G. Cotton. - Режим доступу: http://spi.sagepub.com/content/ 36/2/172.short 3. Călin R. The efficiency of using dynamic games with technical elements from handball during the Physical Education lessons with primary school pupils [Електронний ресурс] / Roman Călin. - Режим доступу: http://www.cnaa.md/en/thesis/ 4631/ 4. Зарядка или Физкультминутка на английском языке [Електронний ресурс]. - Режим доступу: http://kenglish.ru/fizkultminutka/zaryadka-ili-fizkultminutka-na-anglijskom-yazyke/ 5. Полякова Н. В. Интегрированные уроки физкультуры - возможности и перспективы [Електронний ресурс] / Н. В. Полякова // Современная педагогика. - 2014. - № 5. - Режим доступу : http://pedagogika.snauka.ru/2014/05/2349 6. Чаплинская Ю. Г. Физкультминутка на уроках английского языка в свете новых решений о повышении физической активности школьников [Электронный ресурс] / Ю. Г. Чаплинская // Современная педагогика. - 2013. № 10. - Режим доступа : http://pedagogika. snauka.ru/ 2013/10/1906 7. Цікава англійська / авт.уклад. В. Г. Куліш. - Донецьк: Сталкер, 2002. - 320 с.

\section{ОСОБЛИВОСТІ РОЗВИТКУ СУЧАСНИХ ПЕДАГОГІЧНИХ ТЕХНОЛОГІЙ}

Молчанова А. О. Особливості розвитку сучасних педагогічних технологій.

У статті розглянуті основні зміни в освітніх процесах з початку XX століття, що зумовили появу та розвиток відповідних педагогічних технологій. Наведено характеристики певних технологій, визначено основні тенденції розвитку, використання та вдосконалення сучасних педагогічних технологій у навчально-виховному процесі.

Ключові слова: навчально-виховний процес, розвиток, педагогічні технології, 
модернізація, педагог.

Молчанова А. А. Особенности развития современных педагогических технологий.

В статье рассмотрены основные изменения в образовательных процессах с начала XX столетия, которые обусловили появление и развитие соответствующих педагогических технологий. Даны характеристики некоторых технологий, определены основные тенденции развития, использования и совершенствования современных педагогических технологий в учебно-воспитательном процессе.

Ключевые слова: учебно-воспитательный процесс, развитие, педагогические технологии, модернизация, педагог.

Molchanova A. O. The peculiarities of modern pedagogical technologies development.

The main changes in education since the beginning of the 20th century that contributed to the introduction and development of pedagogical technologies are reviewed in the article. The characteristics of certain technologies are given. The main trends of using and improving pedagogical technologies in educational process are defined.

Key words: educational process, development, pedagogical technologies, modernization, teacher.

Розвиток української системи освіти, яка зорієнтована на входження до світового освітянського простору, супроводжується суттєвими змінами в педагогічній теорії та практиці навчально-виховного процесу. Відбувається зміна парадигми освіти: пропонуються інші зміст, підходи, відношення, поведінка, інший педагогічний менталітет. Зростає роль подальшої інтеграції певних чинників: різних освітніх закладів, сім’ї, мікро- й макросоціуму.

Зміст освіти збагачується новими тенденціями, розвитком здібностей суб'єктів освіти оперувати інформацією, творчо розв'язувати проблеми навчання і виховання в нових умовах. Суттєвих змін зазнає технологічна підготовка майбутнього педагога - основа якої полягає в оволодінні технологіями досягнень освітнього стандарту в поєднанні із формуванням особистісних потенціалів суб'єктів навчання.

Системоутворювальне значення відіграють технології розвивальних моделей навчання, міжсуб'єктного діалогу, навчання на основі багатоваріантного навчального плану, імітаційної гри, організації когнітивної діяльності 3 повною орієнтаційною основою, задачного підходу 3 елементами інформаційних технологій $[5$, с. 5]. У зв'язку з цим підвищується роль науки у створенні педагогічних технологій навчання і виховання, адекватних рівню суспільних вимог. За таких умов педагогам необхідно орієнтуватися в широкому спектрі інноваційних технологій, ідей, напрямів, не витрачаючи часу на відкриття вже відомого. Розвиток педагогічної майстерності сучасного педагога неможливий без вивчення широкого арсеналу освітньо-виховних технологій.

У сучасній освіті технології розглядаються як системний метод створення, використання й визначення цілісного навчально-виховного процесу 3 урахуванням інформаційних і людських ресурсів та їх взаємодії. Поняття «педагогічна технологія» може бути представленим трьома аспектами: науковим: педагогічні технології- це частина педагогічної науки, яка вивчає та розробляє цілі, зміст і методи навчання та проектує педагогічні процеси; процесуально-описовим: опис (алгоритм) процесу, сукупність цілей, змісту, методів і засобів для досягнення запланованих результатів навчання; процесуальнодійовим: здійснення технологічного (педагогічного) процесу, функціонування особистісних, 
методологічних та інструментальних педагогічних засобів.

Інноваційні технології розглядаються як закономірні явища в педагогіці, їх упровадження дозволяє усувати суперечності між традиційною системою навчання та потребами в якісно нових технологіях організації навчально-виховного процесу [3, с. 338].

Meта статmi: на основі аналізу ретроспективних змін в освітніх процесах висвітлити особливості розвитку сучасних педагогічних технологій.

Поняття «технології» в освіті вперше з'явилося в науковій літературі у кінці XIX - на початку XX ст. $з$ появою кінопроектора, епідіаскопа, мікроскопа, фотообладнання тощо. До кінця XX століття науково-технічний прогрес зумовив технологізацію не лише численних галузей виробництва, але й позначив технологічний розвиток у галузі культури, гуманітарної галузі знання. Технологізацію вважають об'єктивним процесом модернізації освіти, яка включає також i мистецтво володіння процесом, завдяки чому персоналізується. Технологічний процес завжди передбачає певну послідовність операцій з використанням необхідних засобів та умов. У процесуальному розумінні технологія відповідає на питання: «Як зробити (з чого і якими засобами)?» [4].

Останні узагальнення проблем технологізації освіти, на думку В. Коцура, надають змогу запропонувати варіант періодизації, критеріями якої є суттєві зміни в технологічному проектуванні, розробках технічних засобів, практиці їх застосування, а також динаміка відображення цих змін у педагогічній теорії [2, с. 4].

Перший період (кінець XIX ст. - 30-ті pp. XX ст.) характеризується впровадженням у педагогічну практику технічних засобів навчання, а в теорію входять поняття «технологія в освіті» та «освітня технологія». Уперше у 20-х роках останнє використовувалось у педології, наукових працях із рефлексології (І. Павлов, В. Бехтєрев, А. Ухтомський, С. Шацький). У цей період це поняття поєднувалось 3 «педагогічною технікою» (за А. Макаренко: як сукупністю прийомів і засобів, спрямованих на чітку й ефективну організацію навчальних занять). До педагогічної технології відносилось також уміння оперувати навчальним i лабораторним обладнанням, використовувати наочність.

У 30-ті pр. у працях радянських психологів і педагогів (О. Нечаєв та ін.) використовується поняття «педагогічна технологія». Термін «технологія виховання»вперше використав А. Макаренко. Програми аудіовізуального навчання, створені цього періоду у США, заклали підгрунтя технологічної революції в освіті та спонукали розробленню теоретичних засад педагогічної технології як науки. Важливо, що у професійній підготовці педагогічних кадрів формується технологічний складник, який активно опрацьовували зарубіжні центри фахової підготовки.

Другий період (40-ві - середина 50-х рр. ХХ ст.) позначений упровадженням в освітні процеси розвинутих країн технічних засобів презентації аудіовізуальної інформації. У 1940х pр. виник термін «технологія навчання», який розуміли як використання продукту інженерно-технічної думки в навчанні. Перший освітньо-технологічний проект аудіовізуальної освіти в університеті штату Індіана (США) був розроблений Л. Ларсоном у 1946 p.

Третій період (друга половина 50-х - 70-ті pp. XX ст.) визначається динамічним поступом, поширенням і поглибленням процесів технологізації в педагогічній практиці, що створило підгрунтя для подальшого розвитку теоретичних засад на основі введення поняття «технологічний підхід до навчання». Формуються два аспекти: теоретичний, який ототожнюється 3 поняттям «технологія освіти» або науковий опис педагогічного процесу (мета, форми, методи, засоби, прогнозований результат); та практичний, що асоціюється 3 
поняттям «технологія навчання», яке, у свою чергу, сприймається як використання технічних засобів навчання.

У середині 60-х років широко обговорювалися два напрямки тлумачення терміна «освітня технологія»: як використання технічних засобів і засобів програмованого навчання; як засіб удосконалення навчального процесу задля подолання відставання педагогічних ідей від стрімкого розвитку техніки.

Особливостями цього етапу є:

- розвиток матеріально-технічної бази освіти;

- виникнення технології програмованого навчання (Б. Скіннер, 1954 р.; С. Пейперт та ін., 1968 р.), створення першого персонального комп’ютера «Еппл» (С. Джобс, С. Уозник, 1976 р.). Розробленням ідеї програмованого навчання займалися радянські та вітчизняні педагоги Н. Тализіна, Т. Ільїна, Ю. Машбиць, пізніше - Ю. Бабанський, С. Гончаренко, В. Онищук, В. Паламарчук, І. Тесленко та ін.;

- поглиблення й подальше вдосконалення теоретичної бази: поява таких наукових галузей і навчальних дисциплін, як: інформатика, системний аналіз, теорія телекомунікацій, педагогічна кваліметрія, теорія управління тощо. Виникає поняття «технологія освіти» як науково-педагогічний опис сукупності засобів і методів педагогічного процесу;

- формування тенденції розуміння поняття «педагогічна технологія» як педагогічної системи - цілісного, взаємоузгодженого педагогічного процесу, який шляхом використання технологічних засобів та врахування принципу оптимізації підвищує його ефективність. Суттєвий вплив на розвиток технології як науки мала нова галузь - теорія систем;

- удосконалення й подальше розроблення методичної бази й активізація фахової підготовки педагогів-технологів;

- широке відображення стану розвитку педагогічних технологій у педагогічній періодиці спричинило наукову дискусію щодо змісту понять «технологія в навчанні», «педагогічна технологія», «технологія в освіті», «технологія освіти» [2].

Четвертий період (80-ті pр.- кінець XX ст.) характеризується комплексністю у використанні педагогічних технологій. У документах Асоціації з педагогічних технологій США підкреслювалось: «педагогічна технологія $є$ комплексним інтегральним процесом (люди, ідеї, засоби і способи організації діяльності) для аналізу проблем планування, управління і забезпечення всіх аспектів засвоєння знань» [4].

3 цього часу відбувається осмислення педагогічного процесу з різними деталізаціями поняття «педагогічні технології»:

- це системний, концептуальний, об'єктивований, інваріантний опис діяльності вчителя й учня, спрямований на досягнення освітньої цілі. Це завжди квінтесенція виховної системи, базове утворення, у якому фіксується іiі своєрідність і специфічні особливості теоретичного складу і категоріального апарату;

- це спосіб організації, спосіб думок про матеріали, людей, моделі й системи типу «людина - машина», це перевірка екологічних можливостей проблеми. Педагогічна технологія «передбачає визначення цілей через результати освіти, вираження в діях учнів, надійно усвідомлюваних і визначуваних» [6, с. 93];

- педагогічна технологія - проект певної педагогічної системи, яка реалізується практично [1].

Подальшому розвиткові теоретичних основ технологічного підходу в освіті сприяли праці російських науковців: В. Беспалько. М. Кларін, І. Лернер, В. Монахов та вітчизняних 
педагогів: В. Бондар, С. Бондар, Д. Дегтярьов, О. Максимов, О. Савченко, Г. Сазоненко, П. Сікорський та ін.

На нашу думку, п’ятий, сучасний період (початок XXI ст.) пов'язаний 3 використанням інтерактивних технологій в освіті. Розробляються конкретні педагогічні технології на основі таких процесів, як інформатизація, медіатизація, комп'ютеризація. Їх авторами $\epsilon$ російські та українські педагоги: В. Свдокимов, О. Кіяшко, О. Коваленко, А. Нісімчук, О. Пєхота, Є. Полат, І. Прокопенко, Г. Селевко, С. Сисоєва та ін.

Найбільшого поширення в сучасній психолого-педагогічній літературі набула класифікація педагогічних технологій Г. Селевка. Автор ретельно розглядає майже 50 технологій і поділяє їх на типи за 15 ознаками (рівень використання, філософська основа, методологічний підхід, провідний фактор розвитку особистості, наукова концепція, орієнтація на особистісні сфери та структуру індивіда, характер змісту і структури, основний вид педагогічної діяльності, тип управління навчально-виховним процесом, домінуючі методи і засоби, організаційні форми, засоби навчання, підхід до дитини, спрямування модернізації, категорія педагогічних об’єктів) [8]. Класифікації Г. Селевка оновлюються новими підходами та технологіями.

У практиці вищої школи найбільш оптимальними і перспективними інноваційними педагогічними технологіями, за висновком О. Кіяшко, є: авторська підготовка; відкриті системи інтенсивного навчання, дистанційне навчання; діалогове навчання; етапно-блокова організація навчання; ігрові технології; інтегративно-модульна система; інформаційнокомп'ютерне навчання; контекстне навчання; модульно-рейтингове навчання; особистісно орієнтоване навчання; проблемно-діяльнісне навчання; проектне навчання; рефлексивнотворче навчання; технологія сумісної продуктивної діяльності [10].

За визначенням І. Зязюна, стан і розвиток педагогічних систем у кожну епоху можна поціновувати за рівнем розвитку педагогічних технологій. Простежуючи динаміку цих процесів (від індивідуальної майстерності, тобто мистецтва педагога, до загальновідомих, усталених активних методів і форм освіти) можна відзначити, що саме розвиток засобів учіння і пов'язаних з ними методик, збільшення їх ваги в педагогічних системах від епохи до епохи стимулювало процес технологізації педагогіки в таких характеристиках: стандартизація, уніфікація «освітнього виробництва» в системі масової освіти; винесення творчого процесу (створення й оцінка технологій учіння) на більш високий рівень [4].

Педагогічні технології не можуть бути чимось принципово новим по суті, ніж інші технології. Як і будь-які інші, вони мають свої галузеві (кланові, професійні) особливості і в тому, якими методами і засобами оперують, і в тому, з яким «матеріалом» мають справу. Педагогічні технології відрізняються від виробничих, біологічних, навіть інформаційних. Їхня специфіка виявляється наявністю виховного компонента і необхідності врахування філософського, психологічного та інших аспектів проблеми. Отже, освітня технологія - це специфічний спосіб інтеграції людських знань [4].

Застосування принципу історизму довело, що розвиток педагогічної науки пов'язаний iз постійним пошуком більш досконалих систем, методів та форм підготовки майбутніх педагогів. Більшість дослідників уважають, що в навчальному процесі у всі часи реалізовувалася певна послідовність дій, і тому можна стверджувати, що сучасна педагогічна технологія становить синтез надбань педагогічної науки і практики, поєднання традиційних та інноваційних елементів досвіду навчання, створених на основі досягнень науковотехнічного прогресу, гуманізації й демократизації суспільства.

Дослідження особливостей і можливостей технологічного підходу в освіті, здійснені 
вітчизняною й зарубіжної педагогікою, засвідчують його значний науковий і практичний потенціал щодо забезпечення оптимізації процесу освіти в різних навчальних закладах. Технології викладання, організації навчання й виховання й управління ними з боку педагога нині досить грунтовно розроблено. Удосконалення традиційних форм і методів навчання має здійснюватися одночасно зі створенням інноваційних педагогічних технологій самонавчальної пізнавальної діяльності студентів (учнів, слухачів), які були б адресовані різним категоріям молоді 3 індивідуальними особливостями пізнання. Опанування студентами й учнями технологій самонавчання може стати потужним резервом підвищення їхньої загальноосвітньої та фахової підготовки, якості педагогічного процесу, що $\epsilon$ найважливішою вимогою для сучасної освіти [2, с. 5].

Цілеспрямований пошук ідей, реалізація яких здійснюється шляхом апробацій у формі педагогічного експерименту або пілотного проекту, є джерелом інновацій. Розвиток інновації залежить від того, наскільки соціально-педагогічна дійсність вимагає нової ідеї. Подальше запровадження інновації пов'язане 3 іï переходом у стадію стабільного функціонування [3, с. 338].

Прикладом може стати технологія розвитку критичного мислення, що розроблена як модель інтерактивного навчання науковцями Бостонського центру розвитку етики та виховання. Біля витоків цього напрямку навчання були такі видатні науковці, як: Л. Виготський, Дж. Дьюї, Л. Брунер. Свої наукові дослідження присвятили цій проблемі й вітчизняні дослідники М. Красовицький, О. Бєлкіна, Ю. Стежко та ін.

Технологія розвитку критичного мислення, на думку науковців, $\epsilon$ «вміле відповідальне мислення, що дозволяє людині формулювати надійні вірогідні судження».

Критичне мислення - це здатність людини чітко виокремити проблему, яку необхідно розв'язати; самостійно знайти, обробити і проаналізувати інформацію; логічно побудувати свої думки, навести переконливу аргументацію; здатність мислити мобільно, обирати єдино правильне розв'язання проблеми; бути відкритим до сприйняття думок інших та одночасно принциповим у відстоюванні своєї позиції [7].

Усе більшого поширення у практиці набувають такі педагогічні технології: парацентрична, модульно-рейтингова, індивідуальних освітніх траєкторій, діалогового навчання, контрольно-коригувальна, персонального навчання, індивідуально-бригадна тощо [9].

В останні десятиліття педагогічну громадськість продовжують хвилювати проблеми педагогічних технологій, незважаючи на теоретичні дискусії щодо виявлення змісту цих понять, видів, типів, класифікацій тощо. Загальноприйнятої типології інноваційних педагогічних технологій немає. Їх класифікують за тими ж ознаками, що й інновації, або використовують класифікації педагогічних технологій $[2 ; 10]$.

Аналіз практичного досвіду засвідчує, що до технологій іноді відносять зовсім різні педагогічні елементи (оцінку знань, використання опорних конспектів), нетрадиційні заняття (ділова гра, «Поле чудес», урок-конкурс та ін.). На наш погляд, усі технології, про які йде мова, можна поділити на технології, що розглядаються в широкому і вузькому значенні. До останньої слід віднести аспекти, що стосуються окремих елементів педагогічного процесу (технології оцінки знань, використання опорних конспектів, комп'ютерів тощо). У широкому сенсі - до технологій відносять явища, які стосуються педагогічного процесу в цілому: зміст, діяльність, засоби навчання, організація навчального середовища, способи і форми організації контролю тощо (технології В. Дьяченко, В. Макарова, Ю. Машбиця, В. Монахова, О. Пєхоти, Н. Суртаєвої, О. Шапран та інших). 
Упровадження інноваційних технологій найчастіше відбувається у процесі підвищення кваліфікації в педагогічних ВН3, на курсах у різних методичних центрах та інститутах, а також шляхом самоосвіти. Водночас це ще не забезпечує якісного використання інноваційних технологій у роботі педагога. Причини, що пояснюють цей факт, різні: це неповне усвідомлення інновацій і відповідно відсутність переосмислення своєї власної традиційної діяльності з позицій нововведень; іноді це - бар'єри, які створюються адміністрацією; відсутність схвалення, підтримки з боку колег; відсутність матеріальної зацікавленості; небажання по-іншому розробляти методичне забезпечення для створення нової технології; соціальні, інтелектуальні «лінощі» [9].

Новації впроваджуються за умови їх відповідності культурним пріоритетам певного суспільства, проте значним гальмом у цьому є традиції. О. Герцен писав: «Нове треба створювати в поті чола, а старе саме продовжує існувати і твердо тримається на милицях звички» [9, с. 5].

Доведено, чим міцніше сформовані в педагога звички, що дозволяють йому задовольнятися своїм досягнутим соціальним статусом, тим нижче в нього рівень соціальної мобільності, тим важче буде відбуватися процес його соціалізації у світі, що постійно змінюється. Слід попереджати про це вихованців та випускників вищих навчальних закладів. Вони мають розуміти, що світ характеризується глобальною динамікою соціальних перетворень, гострою постановкою проблеми розвитку здібностей індивіда перемикатися 3 однієї системи поглядів на іншу, щоразу в новій інтерпретації розуміння колишньої системи смислів.

Саме культурологічна компетентність педагога зможе допомогти йому зорієнтуватися в цих змінах. 3 часом нові знання і технології застарівають. Використовується навіть одиниця виміру старіння знань спеціаліста - так званий «період напіврозпаду компетентності», що означає тривалість часу після закінчення навчального закладу, коли в результаті старіння знань, з появою нової інформації, досягнутий рівень компетентності спеціаліста суттєвознижується [9]. Тому підвищення кваліфікації, професійне самовдосконалення має допомогти йому зорієнтуватися в цих змінах.

У психолого-педагогічному сенсі основні тенденції вдосконалення освітніх технологій характеризуються переходом від навчання як репродуктивної функції до навчання як процесу розумового розвитку, що дозволяє використовувати засвоєне; від суто асоціативної, статичної моделі знань до динамічно структурованих систем розумових дій; від орієнтації на середнього студента (учня, слухача) до диференційованих індивідуалізованих навчальних програм; від зовнішньої мотивації учіння до внутрішньої морально-вольової регуляції.

Сутність освітньої технології визначається діалогом старшого (за досвідом) i молодшого (з обмеженим досвідом): батьки - дитина, вихователь - вихованець, учитель учень, професор - студент, професор - аспірант. Важливим $є$ зіставлення відомого, традиційного і нового, або іншого: історичного минулого і сучасної реальності, сучасної реальності i бажаного майбутнього; традиційних цінностей i сучасних новацій, раціонального і емоційно почуттєвого; розуму і душі; гуманітарного і природного тощо [4].

На нашу думку, подальші психолого-педагогічні дослідження педагогічної технології як явища визначаються глибинними смислами, що полягають у такому: педагогічна технологія зводить нанівець педагогічний експромт у практичній діяльності і переводить іiі на шлях попереднього проектування 3 подальшою реалізацією проекту в класі або в навчальній групі; на відміну від поурочних розробок, педагогічна технологія пропонує 
проект навчально-виховного процесу, що визначає структуру і зміст діяльності самого слухача (учня, студента); концептуальність (кожна педагогічна технологія повинна спиратися на певну наукову концепцію, яка передбачатиме філософське, психологічне, дидактичне та соціально-педагогічне обгрунтування освітніх цілей на основі системного підходу); керованість; ефективність (сучасні педагогічні технології існують в умовах конкуренції і мають бути ефективними за результатами та оптимальними затратами, а також гарантувати досягнення певного стандарту навчання); репродуктивність, що припускає можливість використання (повторення, відновлення) педагогічної технології в інших однотипних освітніх установах, іншими суб'єктами.

\section{Література}

1. Беспалько В. Слагаемые педагогической технологии / В. Беспалько. - Москва, 1989. - 139 с. 2. Використання педагогічних технологій у практиці роботи сучасної школи: [зб. наук. праць за матеріалами міжнар. наук.-практ. інтернет-конф., 15-17 лют. 2012 р.] / МОНмолодьспорту України, ДВНЗ «Переяслав-Хмельницький держ. пед. ун-т імені Григорія Сковороди»[та ін.]; наук. ред. Н. П. Оніщенко. - Переяслав-Хмельницький: «Вид-во КСВ», 2012. - 320 с. 3. Енциклопедія освіти / Акад. пед. наук України; головний ред. В. Г. Кремень. - Київ : Юрінком Інтер, 2008. - 1040 с. 4. Зязюн І. А. Філософія педагогічної дії: [монографія] / І. А. Зязюн. Черкаси : Вид. від. ЧНУ імені Богдана Хмельницького, 2008. - 608 с. 5. Концептуальні підходи до розвитку багаторівневої педагогічної освіти в Україні (Проект)/ уклад. : Андрущенко В. П., Зязюн І. А. - Київ, 2011. - 16 с. 6. Лернер И. Внимание: технологии обучения // Советская педагогика. - 1990. - № 3. - С. 91-98. 7. Наволокова Н. П. Технологія розвитку критичного мислення // Педагогічна майстерня. - № 4 (40) квітень 2014 р. - С. 2831. 8. Селевко Г. К. Альтернативные педагогические технологии / Герман Константинович Селевко. - Москва : НИИ школьных технологий, 2005. - 224 с. - (Серия «Энциклопедия образовательных технологий»). 9. Суртаева Н. Н. Инновационные процессы в социализации личности / Н. Н. Суртаева / Проблемы педагогической инноватики в профессиональной школе: [материалы 2-й межрегиональной межотраслевой научно-практической конференции с участием ближнего и дальнего зарубежья]. Ч. 1.- Санкт-Петербург, 2001.- С. 5-7. 10. Шапран О. І. Сучасні педагогічні технології у професійній підготовці вчителів: [навч. посіб.] / за ред. О. І. Шапран. - Переяслав-Хмельницький: «Вид-во КСВ», 2012. - 279 с.

УДК 378.016:811.161.2

Олександра Пальчикова

\section{ПРОБЛЕМИ ПРОГРАМНО-МЕТОДИЧНОГО ЗАБЕЗПЕЧЕННЯ НАВЧАННЯ УКРАЇНСЬКОЇ МОВИ ЯК ІНОЗЕМНОЇ}

Пальчикова О. О. Проблеми програмно-методичного забезпечення навчання української мови як іноземної.

У статті проаналізовано проблеми програмно-методичного забезпечення навчання української мови на підготовчому відділенні. Розглянуто базові навчальні плани та програми, затверджені та рекомендовані Міністерством освіти і науки, молоді та спорту України. Визначено основну мету й завдання у процесі укладання навчальних програм 3 української мови як іноземної.

Ключові слова: соціокультурне оточення, країнознавчий складник, соціокультурна царина, лексичний мінімум, соціокультурна компетентність. 